\title{
ANALISIS PERHITUNGAN HARGA POKOK PRODUKSI DAN PENETAPAN HARGA JUAL PADA DEPOT WIDI KARYA SUNGAI LILIN
}

\author{
CALCULATION ANALYSIS OF COST OF PRODUCTION AND SELLING \\ PRICE ON DEPOT DEPOT WIDI KARYA SUNGAI LILIN
}

\author{
Rano Asoka \\ Sekolah Tinggi Ilmu Ekonomi Rahmaniyah Sekayu \\ ranoasoka09@gmail.com
}

\begin{abstract}
Abstrak : Penelitian ini membahas Analisis Biaya Produksi dan Harga di Depot Widi Karya. Tujuan dalam penelitian ini adalah: untuk mengetahui perhitungan biaya produksi dan penetapan harga di Depot Widi Karya. Metode analitik yang digunakan adalah metode kuantitatif dengan menganalisis biaya produksi dan data jumlah produksi dan harga jual. Perusahaan dapat menentukan bahwa penetapan harga Depot Widi Karya belum dapat mencapai laba optimal, karena dalam konteks harga perusahaan didasarkan pada harga pasar.
\end{abstract}

Kata kunci: Biaya Produksi, Harga Jual, dan Laba

Abstract : This study discusses the Analysis of Cost of Production and Pricing at Widi Karya Depot. The objectives in this study are: to find out the calculation of the cost of production and pricing in the Widi Karya Depot. The analytical method used is a quantitative method by analyzing production costs and data on the amount of production and selling prices. The company can determine that the pricing of Depot Widi Karya has not been able to achieve optimal profit, because in the context of company prices it is based on market prices.

Keywords: Cost of Production, Selling Price and Profit

\section{LATAR BELAKANG}

Dewasa ini dunia usaha mengalami banyak perubahan. Perusahaan-perusahaan, terutama yang bergerak di bidang manufaktur saling berlomba untuk menerapkan teknologi baru, baik yang berhubungan dengan proses produksi maupun yang berhubungan dengan manajemen. Hal ini dilakukan oleh banyak perusahaan untuk memenuhi permintaan pasar yang persaingannya sudah bersifat global. Perusahaan sering mengalami kesulitan dalam melakukan pencatatan dan perhitungan biaya produksi, sehingga berdampak pada penentuan harga pokok produksi. Perhitungan harga pokok produksi yang akurat sangatlah penting bagi perusahaan, sehingga perusahaan dapat menentukan harga jual yang kompetitif. Untuk dapat menentukan harga pokok produksi yang akurat, terlebih dahulu harus diidentifikasi dengan baik unsurunsur biaya yang menentukan harga pokok produksi tersebut.

Depot Widi Karya merupakan perusahaan yang bergerak di bidang industri yang memproduksi 4 (empat) macam produk. Jenis produk yang 
dihasilkan yaitu kusen, pintu, jendela, dan lemari. Berdasarkan hasil wa wancara Penulis kepada pemilik Depot Widi Karya bernama Zainal, diperoleh informasi tentang kegiatan usaha dan sistem produksi. Badan usaha ini memproduksi jika memperoleh pesanan dari konsumen.

Perhitungan biaya produksi pada Depot Widi Karya belum menunjukkan perhitungan yang akurat. Hal ini dibuktikan oleh perhitungan harga pokok produksi Depot Widi Karya hanya membebankan biaya upah, biaya papan/kayu, biaya kaca, dan biaya dempul, plitur, dan paku saja tanpa membebankan biaya over head pabrik, seperti biaya listrik, biaya transportasi, dan biaya penyusutan peralatan. Depot Widi Karya dalam menetapkan harga jual didasarkan harga pasar bukan berdasarkan penetapan harga jual yang seharusnya. terdapat fenomena dimana perhitungan biaya produksi pada Depot Widi Karya belum akurat karena tidak sesuai dengan standar perhitungan harga pokok produksi yang seharusnya, sehingga akan berdampak pada penentuan harga jual yang tidak tepat.

Berdasarkan fenomena tersebut maka Penulistertarik untuk meneliti dengan judul Analisis Perhitungan Harga Pokok Produksi Dan Penetapan Harga Jual Pada Depot Widi Karya Sungai Lilin.

\section{RUMUSAN MASALAH}

Berdasarkan latar belakang yang telah dikemukakan di atas maka rumusan masalah dalam penelitian ini yaitu: bagaimana perhitungan harga pokok produksi dan penetapan harga jual pada Depot Widi Karya Sungai Lilin?

\section{TUJUAN PENELITIAN}

Tujuan penelitian ini adalah untuk mengetahuiperhitungan harg pokok produksi dan penetapan harga jual pada Depot Widi Karya.

\section{TINJAUAN PUSTAKA}

Biaya merupakan komponen data yang memiliki peranan yang sangat penting dalam keseluruhan akuntansi. Dalam akuntansi, pengertian biaya dapat dilihat dari dua sudut, yaitu: pengertian biaya sebagai beban (expenses) dan biaya sebagai harga pokok (cost).

Biaya produksi adalah biayabiaya yang berkaitan dengan pembuatan barang dan penyediaan jasa. Menurut Carter (2011:40), biaya manufaktur juga disebut biaya produksi atau biaya pabrik, biasanya didefinisikan sebagai jumlah dari tiga elemen biaya: bahan baku langsung, tenaga kerja langsung, overhead pabrik.

Menurut Nurlela (2012:12), biaya produksi dibagi menjadi tiga komponen adalah sebagai berikut:

1. Biaya bahan baku (direct material)

2. Biaya tenaga kerja langsung (direct labour)

3. Biaya overhead pabrik (factory overhead)

Menurut

Soemarso (2010:282), harga pokok produksi adalah biaya produksi yang telah diselesaikan selama satu periode, ditambah dengan persediaan awal 
barang dalam proses produksi selama tahun itu dikurangi persediaan akhir barang dalam proses.

Mulyadi (2014:423-427), menyatakan bahwa metode penentuan harga pokok produksi terdiri dari 2 metode yaitu sebagai berikut.

1. Metode full costing yang meliputi sistem biaya historis dan sistem biaya standar.

full costing merupakan metode penentuan biaya produksi, yang terdiri dari biaya bahan baku, biaya tenaga kerja langsung, dan biaya overhead pabrik, baik yang berprilaku tetap maupun variabel.

2. Metode variabel costing

Variabel costing merupakan suatu metode penentuan harga pokok produksi yang hanya memperhitungkan biaya produksi variabel saja.

Menurut Lasena (2013:73), harga jual adalah sejumlah biaya yang dikelurkan perusahaan untuk memproduksi suatu barang atau jasa ditambah dengan persentase laba yang diinginkan perusahaan, karena itu untuk mencapai laba yang diinginkan oleh perusahaan salah satu cara yang dilakukan untuk menarik minat konsumen adalah dengan cara menentukan harga yang tepat untuk produk yang terjual.

Di dalam menentukan harga jual, sebuah perusahaan pasti memiliki tujuan yang akan dicapainya yang akan berpengaruh terhadap perkembangan perusahaan tersebut. Tujuan penetapan harga pada dasarnya berawal dari tujuan perusahaan itu sendiri yang selalu berusaha menetapkan harga barang dan jasa secepat mungkin.
Penetapan harga merupakan suatu proses yang harus dilaksanakan dengan teliti dan tepat. Banyak perusahaan menggunakan berbagai metode yang berbeda dalam bentuk menetapkan harga dasar bagi barang dan jasa yang dihasilkan, oleh sebab itu perusahaan membutuhkan seorang manajer yang mampu mengembangkan dan menerapkan strategi penetapan harga yang dapat memenuhi keinginan perusahaan pada waktu tertentu.

\section{$\underline{\text { Kerangka Penelitian }}$}

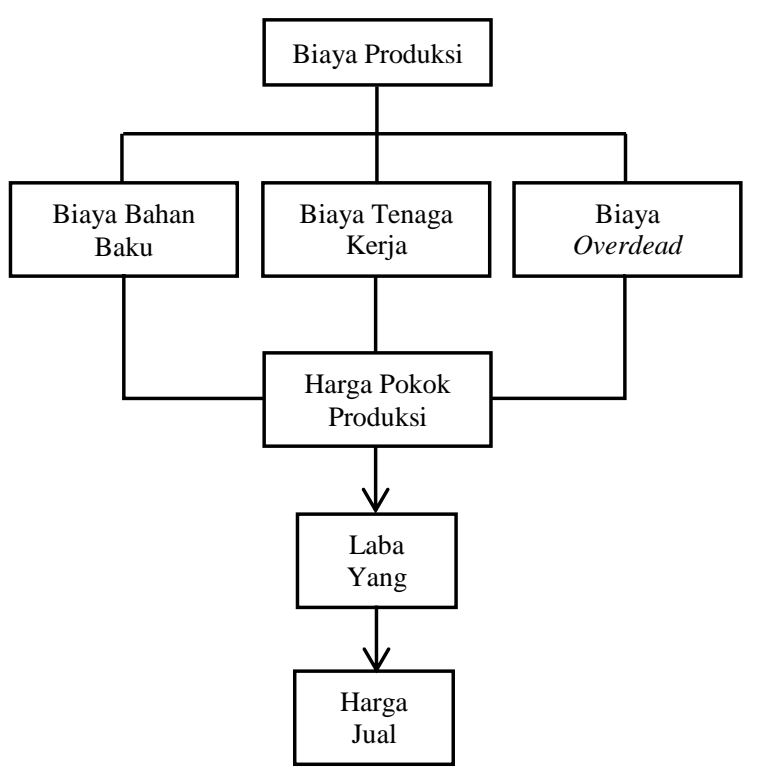

Berdasarkan

kerangka pemikiran di atas dapat dijelaskan bahwa biaya produksi dapat digolongkan menjadi 3 (tiga) yaitu: biaya bahan baku, biaya tenaga kerja langsung, dan biaya overhead pabrik, biaya-biaya tersebut digunakan untuk menghitung besarnya harga pokok produksi untuk mencapai laba yang diharapkan dan menentukan besarnya harga jual 


\section{METODOLOGI PENELITIAN}

Penelitian ini menggunakan metode penelitian kuantitatif. Metode kuantitatif dalam penelitian ini yaitu, mengumpulkan dan menganalisis data berupa data biaya produksi dan data jumlah produksi dan harga jual yang diperoleh dari Depot Widi Karya.

Penelitian ini menggunakan data primer dan sekunder. Dimana data primer didapatkan dengan wawancara kepada pemilik Depot Widi Karya langsung sedangkan data sekunder berupa dokumen dan data yang diperoleh dari Depot Widi Karya.

Teknik pengumpulan data yang digunakan oleh penulis adalah studi lapangan (wawancara dan dokumentasi) dan studi pustaka. Penulis mendapatkan pengetahuan dan landasan berupa teori yang diperoleh dari buku-buku dan literatur serta berbagai laporan. Mengadakan tanya jawab secara langsung guna mendapatkan penjelasan dan informasi yang diperlukan dalam penelitian ini.

Teknik analisis yang akan digunakan dalam penelitian ini adalah teknik analisis kuantitatif dengan cara menggunakan formula dalam perhitungan harga pokok produksi dan penetapan harga jual pada Depot Widi Karya.

\section{PEMBAHASAN}

Analisis Perhitungan Harga Pokok Produksi Pada Depot Widi Karya

Pada Depot Widi Karya perhitungan harga pokok produksi hanya membebankan biaya upah, biaya papan/kayu, biaya kaca, dan biaya dempul, plitur, dan paku saja tanpa membebankan biaya overhead pabrik, seperti biaya listrik, biaya transportasi, dan biaya penyusutan peralatan. Depot Widi Karya dalam menetapkan harga jual didasarkan harga pasar bukan berdasarkan penetapan harga jual yang seharusnya.

Berdasarkan perhitungan harga pokok produksi bahwa perhitungan harga pokok produksi yang selama ini dilakukan oleh Depot Widi Karya belum akurat, karena dalam perhitungan biaya produksi tidak membebankan biaya overhead pabrik, seperti biaya listrik, biaya penyusutan peralatan, dan biaya tenaga kerja tidak langsung. Melainkan hanya membebankan biaya upah, biaya papan/kayu, biaya kaca, dan biaya dempul, plitur, dan paku saja.

Hal ini menyebabkan harga pokok produksi yang dibebankan ke produk tidak mencakup semua biaya yang seharusnya dinikmati produk. Dengan demikian perhitungan biaya produksi menjadi tidak tepat dan akan berdampak penetapan harga jual yang tidak kompetitif.

\section{Perhitungan Harga Pokok Produksi} Menurut Standar Akuntansi

$\begin{array}{lll}\text { Tujuan } & \text { utama } & \text { sistem } \\ \text { manajemen } & \text { biaya } & \text { adalah } \\ \text { memperhitungkan } & \text { harga } & \text { pokok }\end{array}$ produk untuk melaporkan keuangan eksternal dan membantu manajemen dalam mengambil keputusan. Dalam perhitungan harga pokok produk yang berlaku secara eksternal menyatakan biaya dapat diklasifikasikan menurut tujuan khusus atau fungsi yang 
hendak dicapai. Biaya dikelompokkan dalam 2 (dua) kategori fungsional dan utama.

Biaya produksi yaitu biaya yang berkaitan dengan pembuatan barang dan pelayanan jasa dan biaya non produksi adalah biaya yang berkaitan dengan fungsi desain, pengembangan, pemasaran, distribusi, layanan pelanggan, dan administrasi umum. Biaya produksi dapat diklasifikasikan lebih lanjut sebagai bahan langsung, tenaga kerja langsung, dan overhead pabrik. Dalam pelaporan keuangan eksternal, hanya ketiga elemen biaya ini yang dapat dibebankan kepada produk.

Perhitungan Harga Pokok Produksi Menurut Standar Akuntansi

$\begin{array}{ccc}\begin{array}{c}\text { Tujuan } \\ \text { manajemen }\end{array} & \begin{array}{c}\text { utama } \\ \text { biaya }\end{array} & \begin{array}{c}\text { sistem } \\ \text { adalah }\end{array}\end{array}$ memperhitungkan harga pokok produk untuk melaporkan keuangan eksternal dan membantu manajemen dalam mengambil keputusan. Dalam perhitungan harga pokok produk yang berlaku secara eksternal menyatakan biaya dapat diklasifikasikan menurut tujuan khusus atau fungsi yang hendak dicapai. Biaya dikelompokkan dalam 2 (dua) kategori fungsional dan utama.

Biaya produksi yaitu biaya yang berkaitan dengan pembuatan barang dan pelayanan jasa dan biaya non produksi adalah biaya yang berkaitan dengan fungsi desain, pengembangan, pemasaran, distribusi, layanan pelanggan, dan administrasi umum.
Pemakaian Bahan Baku Langsung

Pembebanan biaya bahan baku yang dilakukan pada Depot Widi Karya belum sesuai dengan yang semestinya, seharusnya Depot Widi Karya membedakan antara biaya bahan baku langsung dengan bahan baku tidak langsung. Walaupun pembebanan biaya bahan baku yang dilakukan perusahaan telah memperhitungkan jumlah produk yang dihasilkan.

Tabel 4.1

Depot Widi Karya

Perhitungan Pemakaian Biaya Bahan Baku

Tahun 2017

\begin{tabular}{|c|c|c|c|}
\hline \multirow{2}{*}{$\begin{array}{c}\text { Jenis } \\
\text { Produk }\end{array}$} & \multicolumn{2}{|c|}{$\begin{array}{c}\text { Biaya Bahan } \\
\text { Baku }\end{array}$} & \multirow{2}{*}{$\begin{array}{c}\text { Total } \\
\text { Biaya } \\
\text { Bahan } \\
\text { Baku }\end{array}$} \\
\hline & $\begin{array}{l}\text { Biaya } \\
\text { Papan }\end{array}$ & $\begin{array}{c}\text { Biaya } \\
\text { Kaca }\end{array}$ & \\
\hline $\begin{array}{l}\text { Jen } \\
\text { Pol }\end{array}$ & 80.000 & 65.000 & $\begin{array}{r}145.00 \\
0 \\
\end{array}$ \\
\hline & $\begin{array}{r}00.00 \\
0\end{array}$ & $\begin{array}{r}115.00 \\
0\end{array}$ & $\begin{array}{r}215.00 \\
0\end{array}$ \\
\hline & $\begin{array}{r}5.00 \\
0\end{array}$ & - & $\begin{array}{r}145.00 \\
0 \\
\end{array}$ \\
\hline $\begin{array}{l}\text { Kusen } \\
\text { Gendo } \\
\text { ng }\end{array}$ & $\begin{array}{r}10.00 \\
0\end{array}$ & - & $\begin{array}{r}410.00 \\
0\end{array}$ \\
\hline & $\begin{array}{r}0.00 \\
0\end{array}$ & - & $\begin{array}{r}150.00 \\
\end{array}$ \\
\hline & $\begin{array}{r}0.00 \\
0 \\
\end{array}$ & - & $\begin{array}{r}600.00 \\
0 \\
\end{array}$ \\
\hline & $\begin{array}{r}50.00 \\
0\end{array}$ & & 350.00 \\
\hline $\begin{array}{l}\text { Lemari } \\
\text { Pakaia } \\
\text { n } 2 \\
\text { (dua) }\end{array}$ & $\begin{array}{r}750.00 \\
0\end{array}$ & $\begin{array}{r}150.00 \\
0\end{array}$ & $\begin{array}{r}900.00 \\
0\end{array}$ \\
\hline
\end{tabular}

Sumber: Depot Widi Karya Tahun 2018, data diolah. 
Dari penjelasan table di atas dapat dijelaskan bahwa biaya bahan baku yang dibebankan oleh Depot Widi Karya yaitu biaya papan dan biaya kaca sehingga telah sesuai dengan standar akuntansi yang seharusnya.

\section{Biaya Tenaga Kerja Langsung}

Biaya tenaga kerja merupakan salah satu biaya utama, disamping biaya bahan baku pabrik, yang merupakan salah satu biaya untuk mengubah bahan baku menjadi produk jadi. Penentuan perhitungan dan pembayaran biaya tenaga kerja langsung pada Depot Widi Karya berdasarkan unit produksi. Hal ini menunjukkan bahwa perhitungan biaya tenaga kerja langsung pada Depot Widi Karya sudah benar. Perhitungan biaya tenaga kerja langsung per unit disajikan pada table di bawah ini.

Tabel 4.2

Depot Widi Karya

Perhitungan Biaya Tenaga Kerja Langsung Per Unit

Tahun 2017

\begin{tabular}{|l|c|c|c|}
\hline \multicolumn{1}{|c|}{ Jenis } & $\begin{array}{c}\text { Biaya } \\
\text { Tenaga } \\
\text { Kerja } \\
\text { Langsung } \\
\text { (Rp) }\end{array}$ & $\begin{array}{c}\text { Jumlah } \\
\text { TKL }\end{array}$ & $\begin{array}{c}\text { Total } \\
\text { BTKL } \\
\text { Per Unit } \\
\text { (Rp) }\end{array}$ \\
\hline $\begin{array}{l}\text { Jendela } \\
\text { Polos }\end{array}$ & 50.000 & 2 & 100.000 \\
\hline $\begin{array}{l}\text { Jendela } \\
\text { Kaca } \\
\text { Riben }\end{array}$ & 50.000 & 2 & 100.000 \\
\hline $\begin{array}{l}\text { Kusen } \\
\text { Pintu }\end{array}$ & 50.000 & 2 & 100.000 \\
\hline $\begin{array}{l}\text { Kusen } \\
\text { Gendong }\end{array}$ & 150.000 & 2 & 300.000 \\
\hline
\end{tabular}

\begin{tabular}{|l|c|c|c|}
\hline $\begin{array}{l}\text { Kusen } \\
\text { Jendela }\end{array}$ & 50.000 & 2 & 100.000 \\
\hline $\begin{array}{l}\text { Pintu } \\
\text { Kipas }\end{array}$ & 175.000 & 2 & 350.000 \\
\hline $\begin{array}{l}\text { Pintu } \\
\text { Panel }\end{array}$ & 100.000 & 2 & 200.000 \\
\hline $\begin{array}{l}\text { Lemari } \\
\text { Pakaian 2 } \\
\text { (dua) } \\
\text { Pintu }\end{array}$ & 180.000 & 2 & 360.000 \\
\hline
\end{tabular}

Sumber:Depot Widi Karya Tahun 2018, data diolah.

Dari tabel di atas dapat dilihat bahwa tenaga kerja untuk menyelesaikan satu produk yaitu 2 (dua) orang pegawai, dengan biaya upah masing-masing produk berkisar antara Rp. 50.000 - Rp. 180.000 per orang.

\section{Biaya Overhead Pabrik}

Biaya overhead pabrik merupakan biaya-biaya yang dikeluarkan dalam proses produksi selain biaya bahan baku langsung dan biaya tenaga kerja langsung. Depot Widi Karya dalam hal ini tidak membebankan biaya overhead pabrik. Seharusnya biaya bahan pembantu termasuk biaya overhead pabrik. Untuk menghitung biaya penyusutan maka diperlukan daftar aktiva yang harus disusutkan, yang disajikan pada tabel di bawah ini. 
Tabel 4.3

Depot Widi Karya

Daftar Penyusutan Aktiva Tetap Tahun 2017

\begin{tabular}{|l|c|c|c|}
\hline $\begin{array}{c}\text { Nama } \\
\text { Aset }\end{array}$ & $\begin{array}{c}\text { Harga } \\
\text { Perolehan } \\
\text { (Rp) }\end{array}$ & $\begin{array}{c}\text { Umur } \\
\text { Ekon } \\
\text { omi } \\
\text { (Tahu } \\
\mathrm{n})\end{array}$ & $\begin{array}{c}\text { Total } \\
\text { Penyusuta } \\
\mathrm{n} \\
(\mathrm{Rp})\end{array}$ \\
\hline $\begin{array}{l}\text { Gergaji } \\
\text { Tangan } \\
\text { Listrik }\end{array}$ & 250.000 & 4 & 62.500 \\
\hline $\begin{array}{l}\text { Mesin } \\
\text { Tata } \\
\text { Bobok }\end{array}$ & 2.645 .000 & 4 & 661.250 \\
\hline $\begin{array}{l}\text { Mesin } \\
\text { Ketam } \\
\text { Tangan } \\
\text { Listrik }\end{array}$ & 258.000 & 4 & 64.500 \\
\hline $\begin{array}{l}\text { Mesin } \\
\text { Amplas }\end{array}$ & 1.315 .000 & 4 & 328.750 \\
\hline $\begin{array}{l}\text { Bor } \\
\text { Tangan } \\
\text { Listrik }\end{array}$ & 168.000 & 4 & 42.000 \\
\hline $\begin{array}{l}\text { Mesin } \\
\text { Propil }\end{array}$ & 339.000 & 4 & 84.750 \\
\hline \multicolumn{1}{|c|}{ Total } & & & 1.243 .750 \\
\hline Sumber & $D e p 0 t$ & $W d i$ & \\
\hline
\end{tabular}

Sumber: Depot Widi Karya Tahun 2018, data diolah

Penyusutan aktiva tetap pada Depot Widi Karya menggunakan metode garis lurus. Metode garis lurus adalah suatu metode penyusutan aktiva tetap dimana beban penyusutan aktiva tetap pertahunnya sama hingga akhir umum ekonomis aktiva tetap tersebut.

Tabel 4.4

Depot Widi Karya

Biaya Bahan Pembantu

(Dempul, Plitur dan Paku)

Tahun 2017

\begin{tabular}{|c|c|c|c|c|}
\hline 2 & $\begin{array}{l}\text { Jendela } \\
\text { Kaca } \\
\text { Riben }\end{array}$ & 40.000 & 50 & 2.000 .000 \\
\hline 3 & $\begin{array}{l}\text { Kusen } \\
\text { Pintu }\end{array}$ & 60.000 & 96 & 5.760 .000 \\
\hline 4 & $\begin{array}{l}\text { Kusen } \\
\text { Gendong }\end{array}$ & 90.000 & 26 & 2.340 .000 \\
\hline 5 & $\begin{array}{l}\text { Kusen } \\
\text { Jendela }\end{array}$ & 55.000 & 120 & 6.600 .000 \\
\hline 6 & $\begin{array}{l}\text { Pintu } \\
\text { Kipas }\end{array}$ & 125.000 & 26 & 3.250 .000 \\
\hline 7 & $\begin{array}{l}\text { Pintu } \\
\text { Panel }\end{array}$ & 85.000 & 96 & 8.160 .000 \\
\hline 8 & $\begin{array}{l}\text { Lemari } \\
\text { Pakaian } \\
2 \text { (dua) } \\
\text { Pintu }\end{array}$ & 70.000 & 34 & 2.380 .000 \\
\hline & Total & 565.000 & 518 & 33.290 .000 \\
\hline
\end{tabular}

Sumber: Depot Widi Karya Tahun 2018, data diolah.

Dari tabel di atas dijelaskan bahwa biaya pembantu yang dibebankan yaitu biaya dmpul, plitur, dan paku, dengan biaya berkisar antara Rp. 40.000

Rp. 125.000. Berikut tabel biaya listrik.
Tabel 4.5

Depot Widi Karya

Biaya Listrik

Tahun 2017

\begin{tabular}{|c|l|c|c|c|}
\hline No & $\begin{array}{c}\text { Jenis } \\
\text { Produk }\end{array}$ & $\begin{array}{c}\text { Jumlah } \\
\text { Biaya } \\
\text { Perunit }\end{array}$ & $\begin{array}{c}\text { Tota } \\
1 \\
\text { Unit }\end{array}$ & $\begin{array}{c}\text { Total } \\
\text { BOP }\end{array}$ \\
\hline 1 & $\begin{array}{l}\text { Jendela } \\
\text { Polos }\end{array}$ & 10.000 & 70 & 700.000 \\
\hline 2 & $\begin{array}{l}\text { Jendela } \\
\text { Kaca } \\
\text { Riben }\end{array}$ & 40.000 & 50 & 2.000 .000 \\
\hline 3 & $\begin{array}{l}\text { Kusen } \\
\text { Pintu }\end{array}$ & 10.000 & 96 & 960.000 \\
\hline $0^{4}$ & $\begin{array}{l}\text { Kusen } \\
\text { Gendon } \\
\text { g }\end{array}$ & 15.000 & 26 & 390.000 \\
\hline 5 & $\begin{array}{l}\text { Kusen } \\
\text { Jendela }\end{array}$ & 10.000 & 120 & 1.200 .000 \\
\hline
\end{tabular}




\begin{tabular}{|c|l|c|c|c|}
\hline 6 & $\begin{array}{l}\text { Pintu } \\
\text { Kipas }\end{array}$ & 20.000 & 26 & 520.000 \\
\hline 7 & $\begin{array}{l}\text { Pintu } \\
\text { Panel }\end{array}$ & 20.000 & 96 & 1.920 .000 \\
\hline 8 & $\begin{array}{l}\text { Lemari } \\
\text { Pakaian } \\
2 \text { (dua) } \\
\text { Pintu }\end{array}$ & 25.000 & 34 & 850.000 \\
\hline \multicolumn{7}{|c|}{ Total } & $\begin{array}{r}150.00 \\
0\end{array}$ & 518 & 8.540 .000 \\
\hline
\end{tabular}

Sumber: Depot Widi Karya Tahun 2018, data diolah.

Biaya pada table di atas dapat dijelaskan bahwa biaya listrik yang dibebankan untuk masing-masing produk yaitu berkisar antara Rp.10.000 - Rp. 40.000 untuk perunit. Perhitungan harga pokok produksi yang seharusnya diterapkan oleh Depot Widi Karya degan menggunakan perhitungan pembebanan BOP yang sesungguhnya dapat dilihat pada Tabel 4.7 berikut.

Tabel 4.6

Depot Widi Karya

Biaya Overhead Pabrik

Tahun 2017

\begin{tabular}{|c|c|c|}
\hline No & Jenis BOP & $\begin{array}{l}\text { Jumlah } \\
\text { (Rp) }\end{array}$ \\
\hline 1 & $\begin{array}{l}\text { Biaya } \\
\text { penyusutan }\end{array}$ & 1.243 .750 \\
\hline 2 & $\begin{array}{l}\text { Biaya bahan } \\
\text { pembantu }\end{array}$ & 33.290 .000 \\
\hline 3 & Biaya listrik & 8.540 .000 \\
\hline & Total & 43.073 .750 \\
\hline
\end{tabular}

Dari tabel di atas dapat dijelaskan bahwa biaya biaya penyusutan sebesar Rp. 1.243.750,-Biaya bahan pembantu sebesar Rp. 33.290.000,-. Untuk biaya listrik sebesar Rp. 8.540.000,-. Pembebanan biaya overhead pabrik didasarkan pada persentase jumlah produk yang dihasilkan perhitungan persentase alokasi biaya overhead pabrik adalah sebagai berikut.

1. Jendela Polos $=\frac{70}{518} \times 100 \%=$ $13,51 \%$

2. Jendela Kaca Riben $=\frac{50}{518} \times$ $100 \%=9,65 \%$

3. Kusen Pintu $=\frac{96}{518} \times 100 \%=$ $18,53 \%$

4. Kusen Gendong $=\frac{26}{518} \times 100 \%=$ $5,02 \%$

5. Kusen Jendela $=\frac{120}{518} \times 100 \%=$ $23,17 \%$

6. Pintu Kipas $=\frac{26}{518} \times 100 \%=$ $5,02 \%$

7. Pintu Panel $=\frac{96}{518} \times 100 \%=$ $18,53 \%$

8. Lemari Pakaian 2 (dua) Pintu = $\frac{34}{518} \times 100 \%=6,56 \%$

Berdasarkan hasil perhitungan persentase alokasi BOP maka disusun rekapitulasi persentase alokasi $\mathrm{BOP}$ seperti yang disajikan pada tabel berikut ini

Tabel 4.7

Depot Widi Karya

Persentase Alokasi Biaya Overhead Pabrik

Tahun 2017

\begin{tabular}{|l|l|c|}
\hline No & \multicolumn{1}{|c|}{ Jenis Produk } & $\begin{array}{c}\% \\
\text { Alokasi }\end{array}$ \\
\hline 1 & Jendela Polos & $13,51 \%$ \\
\hline 2 & $\begin{array}{l}\text { Jendela Kaca } \\
\text { Riben }\end{array}$ & $9,65 \%$ \\
\hline 3 & Kusen Pintu & $18,53 \%$ \\
\hline 4 & Kusen Gendong & $5,02 \%$ \\
\hline 5 & Kusen Jendela & $23,17 \%$ \\
\hline 6 & Pintu Kipas & $5,02 \%$ \\
\hline 7 & Pintu Panel & $18,53 \%$ \\
\hline
\end{tabular}




\begin{tabular}{|l|c|c|}
\hline 8 & $\begin{array}{l}\text { Lemari Pakaian } \\
2 \text { (dua) Pintu }\end{array}$ & $6,56 \%$ \\
\hline & Total & $100 \%$ \\
\hline
\end{tabular}

Sumber: Depot Widi Karya Tahun 2018, data di olah

Dari tabel di atas dapat dijelaskan bahwa persentase alokasi biaya overhead pabrik yaitu untuk masing-masing produk yaitu berkisar antara $5,02 \%-23,17 \%$.

Tabel 4.8

Perhitungan Harga Pokok Produksi

Perunit

Tahun 2017

\begin{tabular}{|c|c|c|c|}
\hline \multirow[b]{2}{*}{ Produk } & \multicolumn{3}{|c|}{ Biaya Produksi } \\
\hline & $\begin{array}{l}\text { Biaya } \\
\text { Bahan } \\
\text { Baku }\end{array}$ & $\begin{array}{c}\text { Biaya } \\
\text { Tenaga } \\
\text { Kerja } \\
\text { Langsun } \\
\text { g }\end{array}$ & $\begin{array}{c}\text { Biaya } \\
\text { Overh } \\
\text { ead } \\
\text { Pabrik }\end{array}$ \\
\hline $\begin{array}{l}\text { Jendela } \\
\text { Polos }\end{array}$ & 145.000 & 100.000 & 83.132 \\
\hline $\begin{array}{l}\text { Jendela } \\
\text { Kaca } \\
\text { Riben }\end{array}$ & 215.000 & 100.000 & 83.132 \\
\hline $\begin{array}{l}\text { Kusen } \\
\text { Pintu }\end{array}$ & 145.000 & 100.000 & 83.141 \\
\hline $\begin{array}{l}\text { Kusen } \\
\text { Gendon } \\
\mathrm{g}\end{array}$ & 410.000 & 300.000 & 83.166 \\
\hline $\begin{array}{l}\text { Kusen } \\
\text { Jendela }\end{array}$ & 150.000 & 100.000 & 83.169 \\
\hline $\begin{array}{l}\text { Pintu } \\
\text { Kipas }\end{array}$ & 600.000 & 350.000 & 83.166 \\
\hline $\begin{array}{l}\text { Pintu } \\
\text { Panel }\end{array}$ & 350.000 & 200.000 & 83.142 \\
\hline $\begin{array}{l}\text { Lemari } \\
\text { Pakaian } \\
2 \text { (dua) } \\
\text { Pintu }\end{array}$ & 900.000 & 360.000 & 83.107 \\
\hline
\end{tabular}

Sumber: Depot Widi Karya Tahun 2018, data diolah.
Berdasarkan tabel di atas terlihat bahwa terjadi perbedaan jumlah biaya produksi yang terjadi, perbedaan tersebut disebabkan karena Depot Widi Karya tidak membebankan BOP, dan tidak membedakan antara biaya bahan baku dengan biaya bahan pembantu dalam perhitungan harga pokok produksi. Perbedaan tersebut menimbulkan selisih jumlah biaya produksi per unit. Berdasarkan Tabel 4.8 terlihat bahwa terjadi perbedaan jumlah biaya produksi yang terjadi berdasarkan perhitungan yang seharusnya dengan perhitungan yang dilakukan oleh Depot Widi Karya seperti pada Tabel 4.1, perbedaan tersebut disebabkan Hसparęa Depot Widi Karya Tidak Unimbebankan BOP, dan tidak membedakan antara biaya bahan baku dengan biaya bahan pembantu dalam perhitungan harga pokok produksi. 34erbedaan tersebut menimbulkan selisih jumlah biaya produksi per unit.

398.132 Analisis Perbandingan Perhitungan Harga Pokok Produksi 328.141

79rodjksi memperhitungkan semua unsur biaya produksi yang terjadi dari biaya bahan baku, biaya tenaga kerja, 33. 3 68iaya overhead pabrik dibagi 1.033.qnan hasil produksi dan setiap produk yang dihasilkan oleh Depot Widi Karya.

63Penthifungan harga pokok produksi menurut standar akuntansi dapat 1.29lihaf dari Tabel 4.1. Pada Tabel 4.8 perhitungan harga pokok produksi Depot Widi Karya berbeda dengan perhitungan harga pokok produksi menurut standar akuntansi. Maka dari itu untuk mengetahui seberapa besar selisih antara perhitungan harga 
pokok produksi yang dilakukan oleh perusahaan dengan harga pokok produksi yang seharusnya diterapkan. Dengan memperhitungkan harga pokok produksi yang sebenarnya, maka Depot Widi Karya akan dapat memperhitungkan seberapa besar kemampuan perusahaan dalam menentukan harga jual.

Berdasarkan perbandingan perhitungan harga pokok produksi menurut Depot Widi Karya dengan perhitungan harga pokok produksi yang seharusnya sesuai standar akuntansi. Dengan demikian perusahaan dapat menghitung harga pokok produksi dengan akurat dan penetapan harga jual lebih kompetitif.

Perhitungan Prosentase Laba Kotor Menurut Depot Widi Karya

Depot Widi Karya dalam menetapkan harga jual didasarkan harga pasar bukan berdasarkan penetapan harga jual yang seharusnya dan tidak mempertimbangkan total keseluruhan biaya yang dikeluarkan dalam proses produkssi dan prosentase laba yang dicapai. Berikut Penulis sajikan perhitungan prosentase laba kotor dari harga pokok produksi yang dihitung oleh Depot Widi Karya.

Dari tabel di atas dapat dijelaskan bahwa harga jual yang ditetapkan oleh Depot Widi Karya untuk masing-masing produk berbeda-beda, yaitu disesuaikan dengan jumlah biaya yang dikeluarkan untuk pembuatan produk tersebut.
Perhitungan Prosentase Laba Kotor Berdasarkan Perhitungan Harga Pokok Produksi Menurut Standar Akuntansi.

Dari tabel di atas dapat dijelaskan bahwa laba kotor menurut standar akuntansi lebih kecil dari laba kotor menurut perhitungan Depot Widi Karya. Hal ini dikarenakan pembebanan biaya produksi menurut standar akuntansi lebih akurat. Dengan cara membebankan seluruh biaya yang dikeluarkan. Biaya tersebut yaitu biaya bahan baku, biaya tenaga kerja langsung, dan biaya overhead pabrik. Dari perhitungan harga pokok produksi menurut perusahaan dan menurut standar akuntansi terdapat selisih pada harga pokok produksi. Berikut tabel perbandingan harga pokok produksi menurut perusahaan dan menurut standar akuntansi.

Dari perbandingan Selisih Laba Menurut Depot Widi Karya dan Menurut Standar Akuntasi dijelaskan bahwa laba menurut perusahaan lebih besar dari laba menurut standar akuntansi. Produk yang dijual tidak semua mengalami keuntungan dengan harga pokok produksi yang telah ditetapkan perusahaan. Produk yang mengalami kerugian yaitu kusen gendong dan pintu panel. Hal ini disebabkan karena perusahaan tidak membebankan seluruh biaya dalam menentukan harga jual, seperti biaya bahan baku, biaya tenaga kerja langsung dan biaya overhead pabrik.

\section{KESIMPULAN}

Perhitungan biaya produksi yang diterapkan oleh Depot Widi Karya terdiri dari biaya upah, biaya 
papan/kayu, serta biaya dempul, plitur dan paku. Sedangkan biaya overhead pabrik belum dimasukkan dalam komponen biaya produksi, sehingga perhitungan biaya produksi yang diterapkan oleh Depot Widi Karya belum akurat. Perhitungan biaya produksi menurut perusahaan lebih kecil dari menurut standar akuntansi sehingga berdampak pada perolehan laba menurut perusahaan lebih besar dari menurut standar akuntansi.

Kebijakan penetapan harga jual Depot Widi Karya belum dapat mencapai laba optimal, karena dalam penetapan harga jual perusahaan berpatokan dengan harga pasar.

\section{SARAN}

Berdasarkan pembahasan yang telah di uraikan, maka saran yang dapat diberikan oleh peneliti yaitu :

1. Sebaiknya Depot Widi Karya harus memperhatikan perhitungan harga pokok produksi dengan menggunakan perhitungan harga pokok produksi yang sebenarnya, dengan cara memperhitungkan biaya bahan baku, biaya tenaga kerja langsung dan biaya overhead pabrik yang sesungguhnya, sehingga dapat dicapai biaya produksi yang akurat.

2. Dari hasil analisa perhitungan biaya produksi dan penetapan harga jual, seharusnya perusahaan tidak hanya memperhatikan harga pasar namun dengan menetapkan harga jual berdasarkan perhitungan harga pokok produksi yang akurat agar dapat mencapai laba yang optimal

\section{DAFTAR PUSTAKA}

Carter, William K. 2011. Akuntasi Biaya. Jakarta: Salemba Emat.

Charles T, Horngren. 2014. Akuntansi Biaya. Jilid 1 Edisi Ke 12. Jakarta: Erlangga

Lasena, S.R. 2013. Analisis Penentuan Harga Pokok Produksi Pada PT. Dimembe Nyiur Agripro. Jurnal EMBA, 25 September. Hal.585-592.

Mulyadi. 2014. Akuntansi Biaya. Jakarta: Aditya Media.

Nurlela, Bastian Bustami. 2012. Akuntansi Biaya Teori dan Aplikasi. Jakarta: Graha Ilmu.

Sanusi,Anwar. 2012. Metodologi Penelitian Bisnis. Jakarta: Salemba Empat.

Soemarso, S.R. 2010. Akuntansi Suatu Pengantar. Jakarta : Salemba Empat.

Subagyo. 2010. Metode Penelitian Kuantitatif Kualitatif dan $R \& D$. Bandung: Alfabeta.

Sugiyono. 2012. Metode Penelitian Bisnis. Bandung: Alfabeta. 
